\title{
PARADIGMA PENDIDIKAN \\ UNTUK PEMBANGUNAN YANG BERKELANJUTAN \\ DI TONGYEONG-SI, GYEONGSANGNAMDO, KOREA SELATAN
}

\section{Hastangka}

Pusat Studi Pancasila Universitas Gadjah Mada

Email:hastangka@gmail.com

\section{Abstrak}

Pendidikan untuk pembangunan yang berkelanjutan telah menjadi paradigma global. Paradigma tersebut muncul sebagai bentuk respon dari dinamika dan perdebatan persoalan yang dihadapi masyarakat global yaitu pemanasan global, krisis energi, perubahan iklim, persoalan pangan, serta kerusakan lingkungan. Gagasan utama, dalam paradigma pendidikan tersebut ialah meletakkan pada tiga prinsip utama Pendidikan untuk pembangunan yang berkelanjutan yaitu membangun kondisi lingkungan, sosial-ekonomi, dan budaya yang berkelanjutan. Penelitian ini bertujuan untuk mengeksplorasi dan mendeskripsikan tentang paradigma pendidikan untuk pembangunan yang berkelanjutan di Tongyeong-si, Gyeongsangnamdo, Korea Selatan. Secara lebih lanjut, penelitian ini memfokuskan pada dasar filosofis dan implementasi paradigma pendidikan untuk pembangunan berkelanjutan pada sekolah di kota Tongyeong (Tongyeong-si), Gyeongsang, Korea Selatan. Hasil penelitian ini menunjukkan bahwa dasar filosofi yang diterapkan dalam pendidikan untuk pembangunan berkelanjutan di Kota Tongyeong adalah membentuk masyarakat yang memiliki kepedulian terhadap lingkungan sekitar menuju kota Tongyeong yang berkelanjutan. Pendidikan untuk pembangunan yang berkelanjutan memiliki basis pada rekonstruksi masyarakat yang nantinya dapat mengubah masyarakat di sekitarnya. Paradigma pendidikan ini dapat berkontribusi dalam aspek penguatan pendidikan karakter dan kepedulian terhadap lingkungan bagi masa depan generasi selanjutnya dengan dukungan aktor dari pemerintah dan masyarakat melalui pendekatan kebijakan yang terintegrasi dan program kegiatan yang berkelanjutan,sehingga memiliki dampak dan manfaat bagi tatanan masyarakat yang lebih baik.

Kata kunci:paradigma, pendidikan, pembangunan, sekolah, filosofi. 


\section{Abstract}

Education for sustainable development has become global paradigm recently. This paradigm is a form of dynamic response and debate faced by the global community such as global warming, energy crisis, climate change, food securi$t y$, as well as environmental damage. The main idea, in this paradigm was put in three main principles which are to build environmental, socio-economic and cultural sustainability. This study aims to explore and describe how the paradigm in Tongyeong-si, Gyeongsangnamdo, South Korea. This research focuses on the basic philosophical paradigm and implementation of education for sustainable development at a school in the city of Tonyeong (Tongyeong-si), Gyeongsangnamdo, South Korea. The results indicate that the basic philosophy applied in education for sustainable development in the Tongyeong is formed community who have a concern for the environment has its base in the reconstruction of the society will be able to change the surrounding community. This educational paradigm can contribute in strengthening aspects of character education and awareness of the environment for future generations with the support of actors from the government and society through an integrated approach to policy and program activities that are on going, so it has an impact and benefits for better society.

Keywords: paradigm, education, development, school, philosophy.

\section{PENDAHULUAN}

Pendidikan untuk pembangunan yang berkelanjutan menjadi paradigma pendidikan global sejak Perserikatan Bangsa-Bangsa (United Nations) memperkenalkan dalam forum internasional yang dikenal sebagai KTT Bumi di Rio de Janeiro, Brazil pada bulan Desember 2002 yang dikenal dengan deklarasi Rio. Sejak itu, Pendidikan untuk pembangunan yang berkelanjutan menjadi agenda utama dalam lembaga pendidikan dunia di bawah UNESCO. Awal mula gagasan Pendidikan untuk pembangunan yang berkelanjutan dilatarbelakangi oleh sejumlah persoalan global yang melanda dunia antara lain perubahan iklim (climate change), krisis energi (energy crisis), kelangkaan pangan (food scarcity), krisis kebudayaan, dan hilangnya pengetahuan lokal (Indigenous knowledge), serta, persoalan kerusakan lingkungan yang sampai sekarang ini belum menemukan solusi yang konkret. 
Berbagai kajian dan penelitian tentang perubahan iklim, energi alternatif terbaharukan, serta pangan alternatif yang dilakukan oleh para ilmuwan dunia belum juga mendapatkan hasil yang memuaskan untuk mencapai pada suatu perubahan dunia yang lebih baik dan berkelanjutan. Dalam Tajuk Rencana pada Kedaulatan Rakyat (9 November 2013, hal.14) berjudul “Krisis Ekologi Tetap Menghantui" menjelaskan bahwa kerusakan lingkungan di dunia dan Indonesia sudah semakin akut, eksploitasi sumber daya alam di dunia mencapai 7,3 triliun dollar per tahun. Akibat dari eksploitasi tersebut berdampak pada laju pemanasan global semakin cepat, lenyapnya kemampuan fungsi hutan dalam menyerap karbondioksida, serta kerusakan ekologi semakin meluas. Bukti lain bahwa bencana alam semakin banyak terjadi yaitu iklim tidak menentu, dan perubahan cuaca semakin ekstrim tanpa disadari oleh manusia. Misalnya, Amerika Serikat mendapatkan serangan hawa dingin di sejumlah wilayah Washington, Chicago, Missouri, Wisconsin, New York, dan kota penting lainnya diserang udara dingin yang berdampak pada 2.855 penerbangan ditunda dan 2.332 penerbangan dibatalkan (Kompas, 7 Januari 2014, hal.14). Dalam KTT Dunia tentang Pembangunan Berkelanjutan (Sustainable Development) yang diselenggarakan di Johannesburg, Afrika Selatan pada tanggal 2-4 September 2002 menegaskan pentingnya Sustainable development. Adapun basis filosofi Sustainable development sebagaimana tertuang dalam website UNESCO (http://www.unesco.org/new/en/education/themes/leadingthe-international-agendaleducation-for-sustainable-development/threeterms-one-goal/) adalah:

"seeks to meet the needs of the present without compromising those offuture generations. Sustainable development is a vision of development that encompasses respect for all life - human and non-human - and natural resources, as well as integrating concerns such as poverty reduction, gender equality, human rights, education for all, health, human security and intercultural dialogue."

(berusaha untuk memenuhi kebutuhan masa kini tanpa mengorbankan generasi mendatang. Pembangunan yang berkelanjutan adalah visi pembangunan yang mencakup peng- 
hormatan terhadap semua sumber daya hidup manusia dan non-manusia dan alam, serta memfokuskan pada pengintegrasian pengurangan kemiskinan, kesetaraan gender, hak asasi manusia, pendidikan untuk semua, kesehatan, keamanan manusia dan dialog antar budaya).

Dasar filosofi tersebut menjadi latar belakang pentingnya solusi atas persoalan kemanusiaan dan kealaman melalui pendidikan. Selama ini pendidikan diabaikan dalam mengatasi persoalan global sebagaimana yang terjadi sekarang. Catatan rubrik berita Kompas (4 November 2013,hal.12) berjudul "Soal iklim, peran Perguruan Tinggi belum Optimal" juga menunjukkan bahwa peran perguruan tinggi dalam menyikapi perubahan iklim sebagai akibat dari pemanasan global belum optimal. Sikap intelektual tidak cukup menanggapi perubahan iklim sebatas lewat seminar atau menyebarkan selebaran di jalan, hal ini butuh aksi nyata. Oleh karena itu, dalam KTT Dunia tahun 2002 tentang Pembangunan yang berkelanjutan mulai disinggung pentingnya peran pendidikan untuk terlibat dalam mengatasi persoalan dunia yang semakin kompleks. Rumusan yang ditawarkan dalam deklarasi Johannesburg, kemudian digunakan oleh Perserikatan Bangsa-Bangsa (PBB) untuk memformulasikan paradigma sustainable development ke dalam pendidikan. Akhirnya, Perserikatan Bangsa-Bangsa melalui badan resmi UNESCO mendeklarasikan Education for sustainable development (ESD), 2005-2014 sebagai paradigma pendidikan global untuk memerangi dan merespon isu-isu global pada abad ke-21 ini.

Sejak deklarasi pendidikan untuk pembangunan yang berkelanjutan tahun 2002, berbagai lembaga pendidikan di dunia mencoba untuk memikirkan kembali filosofi pendidikan, program pendidikan, dan kurikulum pendidikan di mana dan pada aspek yang seperti apa pendidikan dapat berperan secara berkelanjutan dalam mengatasi krisis global. Reorientasi sistem pendidikan dan kurikulum menjadi topik yang diperdebatkan dalam implementasi paradigma pendidikan untuk pembangunan yang berkelanjutan. Di satu sisi pendidikan sudah memiliki model dan kurikulum yang baku untuk para siswa, sedangkan di sisi lain, pentingnya untuk membuat suatu perubahan kuriku- 
lum yang berbasiskan pada visi pendidikan untuk pembangunan yang berkelanjutan untuk berkontribusi dalam mengatasi persoalan global.

Pada tahun 2005, paradigma pendidikan untuk pembangunan yang berkelanjutan mulai dikembangkan dan diterapkan di seluruh dunia. Untuk menyukseskan agenda PBB tersebut berbagai badan pendukung mulai dibentuk salah satunya adalah Regional Centre of $E x$ pertise (RCE) sebagai salah satu badan pendukung di bawah naungan United Nations University - Institute of Advanced Studies (UNU-IAS) yang berfungsi untuk menerjemahkan, menyosialisasikan, mengembangkan, dan mempraktekkan nilai-nilai sustainable development di dalam aspek pendidikan yaitu pengetahuan, sikap, dan nilai baik formal maupun non-formal. RCE merupakan organisasi berjaringan yang diakui UNU-IAS untuk menggerakkan program dan menyebarkan gagasan pendidikan untuk pembangunan yang berkelanjutan di seluruh dunia.

Pendidikan adalah masalah khas manusia, hanya manusia yang mempunyai persoalan tentang pendidikan, sebagaimana kodratnya sebagai makhluk rasional yang memiliki cipta, rasa, dan karsa. Apabila suatu bangsa dan manusia mengalami krisis multidimensional berarti pendidikan sedang mengalami krisis dan disorientasi tujuan dan pemaknaan. Oleh karena itu, Manusia memiliki kemampuan untuk dididik dan mendidik dengan tujuan untuk dapat mengatasi persoalan atau krisis tersebut (Suhartono,2009: 62-63, 78-79). Persoalan yang dihadapi oleh dunia tersebut merupakan manifestasi dari ketidakharmonisan antar alam dan manusia, maka, perlu ada yang dikonstruksikan ulang dalam menata pendidikan yang berkelanjutan.

Berbagai permasalahan pendidikan yang terjadi, baik lokal, regional, maupun global telah menunjukkan bahwa pendidikan memiliki peran penting dalam membuat perubahan untuk mengembangkan hidup dan kehidupan manusia lebih baik. Menurut Novak (1977: 28) isuisu terkini pendidikan yang sering dibahas orang pada umumnya adalah apakah pendidikan wajib diperlukan hanya sampai umur 12-14 tahun? Apakah peserta didik harus memiliki lebih banyak kebebasan untuk menentukan bagaimana mereka menghabiskan waktunya di 
sekolah? Haruskah sekolah dihapuskan? Chamberlain dan Kindred (1966: 259) dalam bukunya The Teacher and School Organization, memaparkan temuannya bahwa masalah pendidikan dewasa ini pada dasarnya bertitik tolak tentang perdebatan apa sebenarnya tujuan pendidikan itu?Apakah pendidikan untuk membentuk individu atau membentuk masyarakat? Apakah pendidikan dimaknai untuk mengembangkan intelektual, melestarikan masyarakat, merekonstruksi masyarakat atau untuk mempertemukan kebutuhan individu dan masyarakat. Apakah pendidikan bertujuan semata-mata hanya untuk realisasi diri atau untuk menjalin hubungan antar manusia. Apakah tujuan pendidikan sekedar untuk efisiensi ekonomi atau sebagai tanggung jawab warganegara? Pertanyaan tersebut mencerminkan bagaimana pendidikan harus dikembangkan bagi manusia.

Apabila mencermati perkembangan dunia yang modern sekarang ini berbagai teori dan konsep tentang pendidikan berkembang pesat seperti konsep pendidikan yang dikaitkan dengan agama, alam, ilmu, politik, budaya, sosial, kemanusiaan, lingkungan, kesejahteraan, dan kebahagiaan. Tulisan ini adalah bagian dari hasil penelitian S2 yang dilakukan oleh penulis di Kota Tongyeong Korea Selatan pada tahun 2012. Penelitian ini akan menganalisis secara filsafati bagaimana paradigma pendidikan untuk pembangunan atau yang dikenal sebagai istilah Education for Sustainable Development (ESD)dikembangkan di Korea Selatan khususnya di kota Tongyeong. Secara lebih lanjut, fokus penelitian ini akan memaparkan dua pertanyaan mendasar yaitu: pertama,bagaimana lahirnya paradigma pendidikan dalam konteks global sebagaimana yang dirumuskan oleh lembaga internasional seperti UNESCO yaitu seputar paradigma Pendidikan untuk pembangunan yang berkelanjutan atau Education for Sustainable Development (ESD) memiliki filosofi pendidikan apa?.Kedua,Bagaimana pendidikan dapat dilihat sebagai suatu entitas yang dinamis, universal, dan sarat dengan nilai-nilai.

Penelitian ini mengambil obyek material paradigma pendidikan untuk pembangunan yang berkelanjutan melalui studi kasus di Kota Tongyeong, Korea Selatan dan obyek formalnya adalah Filsafat Pendi- 
dikan. Pengertian Filsafat Pendidikan yang digunakan di sini merujuk pada pemikiran Noddings (2007:xiii) bahwa "Philosophy of Education is the philosophical study of education and its problems" (Filsafat pendidikan adalah studi kefilsafatan tentang pendidikan dan masalahnya). Secara khusus, penelitian ini akan menyoroti bagaimana implementasi Pendidikan untuk pembangunan yang berkelanjutan di Kota Tongyeong, Korea Selatan. Selain itu, penelitian ini akan menggali dan mengeksplorasi bagaimana pemikiran dan konsep yang dibuat, serta aplikasi paradigma pendidikan untuk pembangunan yang berkelanjutan pada sekolah di Kota Tongyeong, Korea Selatan. Penelitian ini akan membatasi kajian yang memfokuskan pada konsep dasar, model/sistem pengembangan pendidikan untuk pembangunan yang berkelanjutan di sekolah, metode yang dikembangkan, dan action plannya dalam perspektif pemikiran Filsafat Pendidikan.

\section{PEMBAHASAN}

\section{Pengertian pendidikan untuk pembangunan yang berkelanjutan}

Berbagai kajian dan penelitian tentang pendidikan untuk pembangunan yang berkelanjutan telah banyak dilakukan oleh para pakar dan ilmuwan lintas disiplin seperti Mahruf dkk (2011) mencoba untuk membedakan istilah Pendidikan tentang pembangunan berkelanjutan, Pendidikan untuk Pembangunan berkelanjutan, dan Pendidikan menuju Pembangunan berkelanjutan.

Pendidikan tentang pembangunan berkelanjutan menekankan pada langkah-langkah berikut yaitu transmisi informasi, sikap perubahan, dan perubahan perilaku. Pendidikan untuk pembangunan berkelanjutan difokuskan untuk mengambil tindakan dalam konteks, membangun kesadaran dan pemahaman praktis, dan sebagai hasilnya adalah komitmen praktis untuk kehidupan yang berkelanjutan, sementara itu, pendidikan menuju pembangunan berkelanjutan menekankan untuk menghasilkan pengetahuan melalui tindakan kritis dan refleksi, kebijakan perubahan dan praktek, akhirnya, mengembangkan warga negara yang aktif dan kritis (Mahruf, dkk, 2011:131-132). 
Konferensi Dunia UNESCO tentang pendidikan untuk pembangunan yang berkelanjutan yang diselenggarakan di kota Bonn, Jerman pada tanggal 31 Maret- 2 April 2009, juga telah menghasilkan deklarasi Bonn yang menjelaskan bahwa Pendidikan untuk pembangunan berkelanjutan berupaya menetapkan arah baru pendidikan dan pembelajaran untuk semua. Deklarasi ini merumuskan pertama, pendidikan untuk pembangunan yang berkelanjutan untuk membantu masyarakat dalam membangun kesadaran untuk mempromosikan pendidikan berkualitas dan melibatkan masyarakat. Hal ini didasarkan pada prinsip-prinsip nilai-nilai dan praktik-praktik yang diperlukan untuk merespon secara efektif terhadap tantangan saat ini dan masa depan. Kedua, membantu masyarakat untuk mengatasi berbagai macam isu-isu kritis yang berbeda antar lain air, energi, perubahan iklim, bencana dan pengurangan risiko, hilangnya keanekaragaman hayati, krisis pangan, risiko kesehatan, kerentanan sosial dan ketidakamanan. Ketiga, pendidikan untuk pembangunan yang berkelanjutan mengedepankan nilai-nilai keadilan, kesetaraan, toleransi, ketercukupan, dan tanggung jawab. Keempat, pendidikan untuk pembangunan yang berkelanjutan menekankan pendekatan kreatif dan kritis, pemikiran jangka panjang, pengembangan inovasi dan pemberdayaan dalam menghadapi situasi tidak menentu (lihat Deklarasi Bonn, 2009).

Rekomendasi Gothenburg (2008) juga menyatakan bahwa tujuan dari pendidikan untuk pembangunan yang berkelanjutan adalah reorientasi pendidikan dalam rangka memberikan kontribusi untuk masa depan yang berkelanjutan untuk kebaikan bersama generasi sekarang dan mendatang. Pendidikan untuk pembangunan yang berkelanjutan mengakui adanya saling ketergantungan dari perspektif lingkungan, sosial, dan ekonomi, dan ketergantungan manusia pada biosfer yang sehat.

Deklarasi Rio tentang Lingkungan dan Pembangunan dan Agenda 21, di Bab 36 dari Agenda 21 (1992) menyatakan bahwa pendidikan, termasuk pendidikan formal, kesadaran masyarakat dan pelatihan harus diakui sebagai sebuah proses di mana manusia dan masyarakat da- 
pat mencapai potensi mereka sepenuhnya. Selain itu, deklarasi ini menekankan bahwa pendidikan sangat penting untuk mempromosikan pembangunan berkelanjutan dan meningkatkan kapasitas lingkungan alam, orang dan isu-isu pembangunan (lihat Dewan Ekonomi dan Sosial, pertemuan regional Kedua tentang pendidikan untuk pembangunan berkelanjutan, Roma, 15-16 Juli 2004, hal. 2).

Ginkel, Hans Van (2006) pada judul presentasi makalahnya "Global Efforts on Education for Sustainable Development and UNU Regional Centres of Expertise on ESD" menggarisbawahi bahwa visi Decade of Education for Sustainable Development (DESD) adalah untuk menciptakan sebuah dunia di mana setiap orang memiliki kesempatan untuk manfaat dari pendidikan yang berkualitas dan mempelajari nilai-nilai, perilaku dan gaya hidup yang diperlukan untuk masa depan yang berkelanjutan dan untuk transisi sosial yang positif. Dia menambahkan bahwa pendidikan untuk pembangunan yang berkelanjutan bukan hanya tentang pendidikan lingkungan tetapi meliputi globalisasi, perdagangan dan pembangunan, pengentasan kemiskinan, konsumsi berkelanjutan dan produksi, keadilan sosial, perspektif gender, dan pemahaman budaya yang berbeda (Ginkel, 2006: 215).

\section{Sekilas tentang Kota Tongyeong (Tongyeong-si)}

Kota Tongyeong terletak di Provinsi Gyeongsang Selatan di negara Korea Selatan. Korea Selatan sendiri merdeka pada tahun 1948 dan terletak di semenanjung di daratan Asia Timur, dengan batas wilayah sebelah timur berbatasan dengan lautan pasifik, sebelah selatan berbatasan dengan selat Jepang, di sebelah barat berbatasan dengan demarkasi militer (garis lintang 380) yang memisahkan Korea Selatan dan Korea Utara. Penduduk Korea Selatan sekitar 50 juta jiwa (sumber: website Kedutaan Besar Korea Selatan).

Tongyeong merupakan kota kecil dan dalam berbagai iklan yang ditayangkan di website pemerintah kota Tongyeong atau iklan-iklan pariwisata yang terpampang di jalan-jalan atau brosur ada banyak predikat yang diberikan bagi kota Tongyeong yaitu the land of Sea, The World's best oysters and pearls, kota industri perikanan, kota wisata, kota 
mutiara, kota kebudayaan, kota kapal, dan kota layak anak. Dalam sejarahnya kota Tongyeong di mulai sebagai tempat pelabuhan angkatan laut pada abad ke-16. Pada waktu itu terjadi peperangan di pulau Hansan, ketika Jenderal Lee Yi Sun-sin, mengalahkan invasi Jepang, yang dikenal dengan salah satu dari empat peperangan laut terbesar di dalam sejarah perang laut dunia. Nama "Tongyeong", berasal dari kata "Tong Je Yeong" yang berarti naval headquarters (Booklet RCE Tongyeong,2007).

Kota Tongyeong merupakan kota kelahiran para artis terkemuka seperti pengarang lagu Yun Isang; penulis puisi, Yu Chihwan, Kim Choonsoo; Novelis terkenal, Park Gyeong-li; Peluksi, Jeon Hyeog-lim. Adapun, karakteristik Kota Tongyeong dapat disoroti dari tiga aspek yaitu pertama terkait dengan sosial menunjukkan bahwa dinamika sosial masyarakat Kota Tongyeong cenderung masih eklusif, kurang terbuka pada pembaharuan dan belum terhubungkan dengan masyarakat luas, serta interaksi masyarakatnya masih homogen. Berdasarkan data statistik tahun 2012 dari Kota Tongyeong jumlah penduduk di kota tersebut adalah 435,000 jiwa. Kedua, terkait dengan ekonomi bahwa mata pencaharian utama penduduk Kota Tongyeong adalah tergantung pada sektor perikanan laut dan pariwisata. Di Kota Tongyeong banyak ditemukan nelayan dan usaha pembibitan dan pembudayaan kerang laut. Kota yang terletak di sebelah ujung paling selatan Negara Korea Selatan ini memiliki potensi dalam pembudidayaan ikan, mutiara, dan kerang laut.

Profesor Choi Byeong Dae, Dosen Marine College, Universitas Gyeongsang menjelaskan bahwa perekonomian warga kota Tongyeong hanya tergantung pada tiga sektor itu yaitu perikanan laut, pariwisata, dan pembuatan kapal, namun yang ketiga sekarang ini mulai bangkrut dan sudah menurun akibat dari krisis di negara Eropa dan Amerika (wawancara dengan Profesor Choi, 20 April 2012 02:00). Ekonomi di Kota Tongyeong mengalami penurunan dan industri perikanan yang menyumbang pendapatan terbesar masyarakat juga mengalami kesulitan karena penurunan daya beli masyarakat. Pada sektor pariwisata, beberapa tempat di kota Tongyeong memiliki nilai jual 
kepariwisataan yaitu Yi sun Park, cable car, dan pasar ikan Tongyeong (Tongyeong traditional market). Ketiga, Pendidikan di kota Tongyeong umumnya masih terbatas pada fasilitas dan akses bagi siswa dan guru untuk mendapatkan informasi dari luar seperti kegiatan dan programprogram yang ditawarkan oleh pemerintah selalu datang terlambat atau tidak mendapatkan akses informasi tersebut karena kota Tongyeong adalah kota kecil.

\section{Potret Pendidikan di Kota Tongyeong}

Kota Tongyeong memiliki jumlah sekolah yang sedikit. Berdasarkan data Dinas Pendidikan Kota Tongyeong terdapat 21 Sekolah dasar negeri (SD), 11 Sekolah Menengah Pertama (SMP) yang terdiri 9 Sekolah negeri dan 2 sekolah swasta. 6 Sekolah Menengah Atas (SMA) yang terdiri dari 4 Sekolah Negeri dan 2 Sekolah Swasta. Kehidupan pelajar di kota Tongyeong setiap harinya disibukkan dengan aktivitas sekolah dan rutinitas untuk belajar. Para pelajar pada umumnya di Kota Tongyeong tidak memiliki waktu bermain.

Bagi siswa pelajar SMP dan SMA kelas tiga mereka harus mempersiapkan diri untuk menghadapi ujian nasional. Setiap harinya siswa-siswi pulang hingga larut malam untuk mengikuti kursus mata pelajaran yang diberikan di sekolah atau lembaga bimbingan di luar sekolah. Jam Sekolah di Kota Tongyeong untuk tingkat Sekolah Dasar mulai pada pukul 07:00 pagi hingga 12:30, kemudian dilanjutkan kegiatan ektrakurikuler sampai jam 16:00. Fasilitas yang diberikan sekolah kepada murid SD adalah makan siang gratis dengan berbagai menu yang berbeda setiap harinya, biaya pendidikan gratis, dan fasilitas sekolah yang lengkap untuk menunjang pembelajaran seperti setiap ruang kelas disediakan komputer, Televisi merek Samsung atau LG, LCD, halaman yang luas, dan perpustakaan yang lengkap dan luas dengan berbagai macam buku bacaan dalam bahasa Korea. Misalnya, di Yongnam dan Inpyeong elementary school merupakan sekolah favorit bagi siswa-siswi SD, banyak orang tua ingin anaknya sekolah ke tempat ini karena memberikan pelayanan pendidikan yang bagus dengan 
fasilitas gedung yang luas dan nyaman (hasil observasi April-Mei 2012).

Siswa-siswi Sekolah Menengah Pertama (SMP) mulai masuk sekolah setiap harinya pada pukul 07:00 sampai dengan pukul 16:00. Setelah itu, mereka mengikuti banyak kegiatan lain di luar sekolah yaitu mengerjakan tugas sekolah, mengikuti bimbingan belajar di luar sekolah hingga sampai pukul 21.00-22.00 malam. Fasilitas yang diberikan sekolah untuk menunjang proses pembelajaran juga sangat lengkap. Di Tongyeong girl's Middle School, memiliki berbagai fasilitas antara lain ruang hall indoor dan outdoor untuk olah raga, dining hall sebagai tempat makan siang bersama, fasilitas kelas yang lengkap terdiri TV, komputer, AC, dan LCD, serta perpustakaan yang lengkap dengan audiovisual (Observasi yang dilakukan oleh penulis April-Mei 2012).

Pada Sekolah Menengah Atas (SMA), siswa dan siswinya mulai masuk sekolah pada pukul 07:00 pagi sampai pada pukul 17:00 sore secara formal dan kemudian mereka ada jam tambahan bagi kelas 2 dan 3 terutama untuk latihan soal-soal menghadapi ujian nasional. Jadi sudah sejak SMP sampai SMA mereka dipersiapkan untuk menghadapi ujian nasional. Bagi siswa kelas 3 SMA mereka bisa pulang sampai jam 23:00 malam setiap harinya karena mereka harus mempersiapkan diri bisa lulus ujian nasional. Umumnya, anak sekolah di Kota Tongyeong digunakan sebagai batu loncatan bagi para siswa-siswi yang belajar di Kota Tongyeong untuk melanjutkan sekolah yang lebih tinggi di kota lain atau mencari pekerjaan di daerah lain.

\section{Pendidikan untuk pembangunan yang berkelanjutan di Kota Tongyeong}

Konsep pendidikan untuk pembangunan yang berkelanjutan mulai diperkenalkan di kota Tongyeong ketika lembaga koordinatif yang dibentuk oleh United Nations University (UNU) yaitu yang dikenal sebagai Regional Centre of Expertise (RCE) atau TongyeongEducational Foundation mulai berdiri di kota Tongyeong dengan nama RCE Tongyeong. RCE Tongyeong adalah badan koordinatif yang bertujuan untuk menghubungkan komunitas, masyarakat, dunia pendidikan, dan 
perusahaan dalam mentransformasikan pengetahuan, keterampilan, dan pengalaman tentang konsep pembangunan yang berkelanjutan kepada seluruh lembaga pemerintah maupun non pemerintah di kota tersebut dan sekitarnya.

Menurut sejarahnya, RCE Tongyeong diresmikan oleh United Nations University (UNU) pada bulan Oktober 2005. RCE Tongyeong berkantor di pemerintah Kota Tongyeong dengan staf yang terdiri dari berbagai latar belakang disiplin ilmu. Tujuan dari RCE Tongyeong adalah membuat rumusan dan menghubungkan program-program yang berkaitan dengan pendidikan untuk pembangunan yang berkelanjutan serta memasyarakatkan program tersebut kepada dunia pendidikan, komunitas, dan perusahaan.

Adapun tujuan utama RCE Tongyeong yang telah dirumuskan adalah pertama, membangun kerjasama dengan RCE yang ada di seluruh dunia, untuk dapat berkontribusi dalam upaya global mendukung pembangunan yang berkelanjutan. Kedua, berpartisipasi aktif bersama stakeholder yang ada, dengan cara membangun kemitraan dengan masyarakat umum. Ketiga, membangun jaringan dalam bidang pendidikan baik formal dan informal. Keempat, menyediakan kesempatan untuk belajar kewarganegaraan global, keberagaman budaya, dan lingkungan, dengan jalan memperkuat pemimpin lokal untuk membangun paradigma pembangunan yang berkelanjutan. Kelima, Meningkatkan kesadaran ekologi dan aktivitas manusia, dengan jalan meningkatkan kualitas hidup dan menciptakan kota yang berkelanjutan. Keenam, membangun model pembangunan yang berkelanjutan ala Korea untuk menjadi model percontohan di negara lain.

RCE Tongyeong selalu bekerjasama dengan lembaga pendidikan, baik formal dan non-formal untuk menggeser paradigma pendidikan yang berpihak pada pembangunan yang berkelanjutan. Persoalan yang ada terkait dengan masalah pembangunan yang berkelanjutan di kota Tongyeong adalah masalah lingkungan yang akut,seperti kerusakan lingkungan di pesisir pantai dan laut akibat limbah industri perikanan, pembuatan kapal, pencemaran air laut oleh karena sampah yang dibuang oleh masyarakat, nelayan, dan turis lokal dan domestik 
ketika menaiki kapal. Polusi air laut dan ketidakseimbangan ekologis dan lunturnya budaya lokal, menjadi isu-isu yang muncul di kota Tongyeong.

Dalam konteks pendidikan, kesadaran para generasi muda atau peserta didik dalam menanggapi persoalan pembangunan yang berkelanjutan sangat minim. Hal tersebut dapat diketahui dari banyak siswa-siswi di kota Tongyeong tidak mengetahui mengapa bumi ini penting untuk tetap dijaga keberlanjutannya; bagaimana tetap menjaga lingkungan tetap bersih, indah, dan nyaman, bagaimana peran pendidikan dalam memberikan sumbangsih yang positif bagi keberlangsungan masa depan generasi selanjutnya. Melalui RCE Tongyeong, para pembuat kebijakan pendidikan, stakeholder, dan organisasi masyarakat dilibatkan untuk merumuskan isu-isu apa yang terpenting untuk memasukkan konsep pembangunan yang berkelanjutan dalam dunia pendidikan, dan pendekatan pendidikan yang seperti apa supaya para peserta dididik memahami makna pendidikan untuk pembangunan yang berkelanjutan, serta melaksanakannya dalam kehidupan seharihari.

Ruang lingkup kegiatan dari RCE Tongyeong dalam mentransformasikan nilai-nilai pendidikan untuk pembangunan yang berkelanjutan adalah menekankan aspek kesadaran siswa untuk memahami arti penting lingkungan yang bersih, sehat, dan nyaman. Konsep yang diberikan oleh RCE Tongyeong adalah bagaimana menyelamatkan biota laut dan mengurangi polusi air atau laut, menekankan kerusakan lingkungan akibat dari ulah manusia seperti: membuang sampah sembarangan, makan tidak habis, melestarikan budaya lokal dan menjaga dan menghemat penggunaan energi dan air bersih secara bijak. Kondisi sosio-geografis kota Tongyeong menjadi latar belakang RCE Tongyeong untuk memberikan edukasi dan promosi tentang pentingnya pendidikan untuk pembangunan yang berkelanjutan di kota tersebut. RCE Tongyeong memiliki peranan untuk mempromosikan pembangunan yang berkelanjutan melalui pendidikan di kota Tongyeong dengan jalan mendorong praktek-praktek berkelanjutan dalam setiap aspek kehidupan. RCE Tongyeong juga mendorong pengembangan 
eco-tourism dan edu-tourism untuk berkontribusi pada pengembangan ekonomi lokal dengan cara yang berkelanjutan.

Pada tahun 2005, Kota Tongyeong melalui Regional Centre of Expertise ( $R C E$ ) Tongyeong mengembangkan program pendidikan untuk pembangunan yang berkelanjutan dalam hal merespon isu-isu lokal, regional dan global. RCE Tongyeong mengembangkan berbagai program untuk mendukung implementasi pendidikan untuk pembangunan yang berkelanjutan di sekolah. Program yang dikembangkan oleh RCE Tongyeong adalah pengembangan materi pelajaran untuk digunakan pada tingkat sekolah dasar, sekolah menengah pertama, dan sekolah menengah atas.

Upaya yang telah dilakukan oleh RCE Tongyeong untuk meyakinkan kepada para stakeholder sekolah seperti kepala sekolah, guru, orang tua siswa adalah mengajak mereka untuk berdialog bersama Dinas Pendidikan Kota Tongyeong. Persoalan yang diangkat dalam pendidikan untuk pembangunan yang berkelanjutan di sekolah-sekolah adalah membahas tentang kesadaran lingkungan yang bersih, sehat, dan berkelanjutan. Siswa diberikan pemahaman tentang pentingnya membuang sampah pada tempatnya, makan secukupnya, menggunakan energi secara bijak, makan dengan bijak.

Stretagi yang digunakan di Kota Tongyeong dalam merancang dan pengembangan pendidikan untuk pembangunan yang berkelanjutan adalah pertama, memberikan sosialisasi,pendampingan, dan advokasi terkait dengan pengertian, ruang lingkup, dan makna pendidikan untuk pembangunan yang berkelanjutan bagi masyarakat dan para siswa. Kedua, membangun jaringan kemitraan strategis baik dengan guru, sekolah, wali murid, universitas, komunitas, dan industri untuk mendukung secara berkelanjutan program dan pemikiran pendidikan untuk pembangunan yang berkelanjutan. Ketiga, membuat pelatihan dan penguatan kapasitas sumber daya manusia untuk melaksanakan pendidikan untuk pembangunan yang berkelanjutan di Kota Tongyeong. Keempat, mengadakan kegiatan kemitraan dan kebersamaan untuk menyukseskan pendidikan untuk pembangunan yang 
berkelanjutan dengan membuat program green school, empty plate campaign, dan ESD school competition, program Bridge to the world.

Antusiasme masyarakat terhadap pendidikan untuk pembangunan yang berkelanjutan dapat ditunjukkan dari peran guru dan siswa dalam mendukung dan melakukan program-program yang dirancang oleh sekolah, RCE Tongyeong, bersama masyarakat untuk menumbuhkan kesadaran peserta didik dalam memahami hakikat manusia, alam, dan lingkungan di sekitarnya tanpa mengurangi masa depan generasi selanjutnya.

RCE Tongyeong menjadi think tank dalam pelaksanaan pendidikan untuk pembangunan yang berkelanjutan di kota Tongyeong, yang disebut sebagai Tongyeong Education Foundation for sustainable development dengan visinya "Learning and Sharing for Sustainable Future". RCE Tongyeong melakukan perubahan nama menjadi yayasan pada tahun 2008 dan telah mempersiapkan berbagai macam program setelah di launching pada tahun 2010. Yayasan pendidikan Tongyeong untuk pembangunan yang berkelanjutan dipimpin oleh Dr.Eun Kyung Park dan sejumlah direktor pelaksana lainnya. Tujuan dari Yayasan pendidikan Tongyeong untuk pembangunan yang berkelanjutan adalah mempromosikan pendidikan untuk pembangunan yang berkelanjutan melalui proyek dan pengembangan bakat-bakat setiap manusia untuk masa depan yang berkelanjutan, mendukung pembelajaran sepanjang hayat yang menyenangkan, mempromosikan pariwisata edukatif, dan mencari jalan untuk menuju Asia masa depan yang keberlanjutan. Komite yang berpartisipasi dalam lembaga ini terdiri dari media, pakar, akademisi, konsultan, dan dinas pendidikan.

Strategi yang dilakukan dalam mengimplementasikan pendidikan untuk pembangunan yang berkelanjutan pada sekolah di Kota Tongyeong dapat dilihat dari upaya RCE Tongyeong yang melakukan sinergi dengan Dinas Pendidikan Kota Tongyeong, masyarakat, Komite Sekolah, guru dan wali murid untuk membahas dan menceritakan persoalan-persoalan yang terjadi di kota Tongyeong. Persoalan tersebut di bagi menjadi dua yaitu pertama, persoalan internal terkait masalah sekolah, pendidikan di sekolah, kurikulum, siswa, dan guru. Kedua, persoalan eksternal terkait dengan lingkungan sosial, masyarakat, 
kebijakan pemerintah tentang pendidikan, dan isu-isu global dalam konteks isu tentang pembangunan yang berkelanjutan.

Guru dan Murid mulai banyak belajar tentang apa itu pendidikan untuk pembangunan yang berkelanjutan, mengapa itu penting, dan seberapa jauh dampaknya. Pada awalnya, sebelum diperkenalkan pendidikan untuk pembangunan yang berkelanjutan di sekolah, para guru dan murid terlalu fokus pada dirinya dan hanya memikirkan tentang hidupnya di depan (hasil wawancara dengan guru SD Yongnam, April 2012). Penemuan dalam penelitian ini menunjukkan bahwa guru di kota Tongyeong memberikan definisi yang beragam terkait dengan status mereka sebagai guru. Hakikat guru adalah profesi untuk memberikan dedikasi dan mencintai murid-murid yang diajarkannya. Menurut seorang guru di Tongyeong mengatakan bahwa hakikat pendidikan adalah tidak hanya sekedar mendidik tau mengajar tetapi yang terpenting adalah relasi antara guru dan peserta didik (Wawancara dengan guru di Tongyeong girl's middle school, 24 Mei 2012 16: 49).

Guru adalah fasilitator bagi peserta didik yang dapat memfasilitasi kebutuhan siswa secara maksimal. Guru adalah orangtua di sekolah bagi anak-anak didik dan harus mengajar dengan hati. Berpijak dari definisi dari para guru yang mereka ungkapkan (Tongyeong girl's middle school, Inpyeong elementary school, Yongnam elementary school, Dongwon high school), dapat terlihat bagaimana guru dan murid saling berinteraksi secara dekat, program pendidikan untuk pembangunan yang berkelanjutan yang ditawarkan di sekolah menjadi suatu hal yang dapat diterima dan beberapa sekolah termasuk guru dan murid mengalami perubahan dan melihat dunia yang begitu luas. Guru tidak lagi memfokuskan pada diri mereka tetapi juga melihat bagaimana mereka perlu mendidik para peserta didik untuk peduli terhadap sesama manusia, lingkungan alam sekitarnya, dan masa depan generasi selanjutnya. Dampak yang didapatkan setelah sekolah mendapatkan materi dan program tentang Pendidikan untuk pembangunan yang berkelanjutan adalah para peserta didik akhirnya menyadari pentingnya lingkungan yang bersih, memaknai kehidupan lebih arif, dan peduli terha- 
dap kehidupan di sekitarnya (hasil wawancara dengan guru 24 Mei 2012).

Menurut Elias, Nakayama dan Hargreaves (2005: 13) menunjukkan bahwa pengembangan pendidikan untuk pembangunan yang berkelanjutan di Korea memberikan pemahaman kepada beberapa orang tentang pentingnya pembangunan berkelanjutan. Sementara itu, tantangan pendidikan untuk pembangunan yang berkelanjutan di Korea adalah bagaimana menghubungkan antara pendidikan, secara umum, dan pembangunan berkelanjutan ternyata tidak mudah dibuat, terutama dalam hal hubungan antara pendidikan nilai dan pembangunan berkelanjutan. Ransoo (1984) menekankan bahwa isu-isu umum pada Pendidikan Korea adalah bagaimana siswa dapat beradaptasi dan bertahan pada konteks sosial dan global. Menurut risetnya pendidikan di Korea perlu mempertimbangkan perubahan sosial dalam masyarakat dan konteks global. Kompleksitas administrasi, manajemen, dan hambatan sistem pendidikan menjadi penting untuk memperhatikan bagaimana pendidikan dapat memberikan kontribusi pada perubahan sosial untuk masa depan generasi muda dan memiliki strategi reformasi. Lebih lanjut ia menekankan agar lembaga pendidikan tidak terisolasi dari masyarakat (Ransoo, 1984: 97-130).

\section{SIMPULAN}

Berdasarkan hasil penelitian ini menunjukkan bahwa pertama, hakikat pendidikan untuk pembangunan yang berkelanjutan adalah sebuah paradigma pendidikan untuk penguatan kapasitas manusia dalam memenuhi kebutuhan hidupnya tanpa mengurangi kapasitas/ kemampuan generasi mendatang untuk memenuhi kebutuhan dasarnya. Pendidikan untuk pembangunan yang berkelanjutan didasarkan pada tiga aspek berkelanjutan yaitu sosial-budaya yang berkelanjutan, ekonomi yang berkelanjutan, dan lingkungan yang berkelanjutan.

Kedua, hasil kajian dan penelitian yang telah dilakukan melalui studi kasus di kota Tongyeong ditemukan bahwa pendidikan untuk pembangunan yang berkelanjutan dapat terintegrasi dalam pendidikan dan kurikulum yang sudah ada selama dalam kerangka kepentingan dan kebutuhan, serta kondisi di suatu wilayah atau negara tersebut. 
Namun, penerapan dalam konteks kurikulum, materi, dan metode belum tentu berdampak secara signifikan terhadap perubahan perilaku peserta didik selama lingkungan sosial masyarakat di sekitarnya belum mengalami perubahan.

Ketiga, dasar filosofi yang diterapkan dalam pendidikan untuk pembangunan yang berkelanjutan di Kota Tongyeong adalah membentuk masyarakat yang memiliki kepedulian terhadap lingkungan sekitar menuju kota Tongyeong yang berkelanjutan. Pendidikan untuk pembangunan yang berkelanjutan memiliki basis pada rekonstruksi masyarakat yang nantinya dapat mengubah masyarakat di sekitarnya. Paradigma pendidikan ini dapat berkontribusi dalam aspek penguatan pendidikan karakter dan kepedulian terhadap lingkungan bagi masa depan generasi selanjutnya dengan dukungan aktor dari pemerintah dan masyarakat melalui pendekatan kebijakan yang terintegrasi dan program kegiatan yang berkelanjutan,sehingga memiliki dampak dan manfaat bagi tatanan masyarakat yang lebih baik.

Keempat, berdasarkan analisis filsafati, konsep pendidikan untuk pembangunan yang berkelanjutan sebagai upaya untuk membangun tatanan masyarakat baru yang lebih baik belum menunjukkan dampak yang besar. Terbukti bahwa sekolah yang ada di kota Tongyeong belum mengubah visi dan misi pendidikannya untuk reformasi sosial. Metode dalam mengajarkan atau lebih tepatnya mempromosikan pendidikan untuk pembangunan yang berkelanjutan masih konvensional yang kemudian ditambah dengan kegiatan luar sekolah seperti field trips ke beberapa negara untuk memperlihatkan peserta didik tentang kehidupan negara tersebut dari aspek budaya, sosial, ekonomi, dan lingkungan dan studi kasus tentang masalah lingkungan dan budaya. Aplikasi paradigma pendidikan untuk pembangunan yang berkelanjutan di Kota Tongyeong, Korea Selatan,lebih menunjukkan aktivitas di luar sekolah daripada di dalam sekolah karena lebih cepat dapat memberikan dampak positif bagi peserta didik untuk mengerti keadaan lingkungan sekitarnya. Program yang ditawarkan dalam konteks pendidikan untuk pembangunan yang berkelanjutan di ditekankan dua hal yaitu terkait pelestarian lingkungan dan budaya di kota Tongyeong.Pendidikan untuk pembangunan yang berkelanjutan adalah 
gagasan untuk merespons dampak dari krisis global dan lingkungan kronis seperti kerusakan lingkungan, pencemaran, kerusakan hutan, polusi udara, polusi air, krisis energi, krisis pangan, krisis kemanusiaan, dan krisis kebudayaan yaitu membentuk tatanan sosial baru yang lebih baik dan bermartabat, serta bersahabat dengan lingkungan. Kurikulum yang dikembangkan dan direkonstruksi dalam pendidikan untuk pembangunan yang berkelanjutan adalah peserta didik ditekankan dalam keterlibatannya pada masalah nyata di masyarakat dan isu-isu global.

Kelima, sumbangsih paradigma pendidikan untuk pembangunan yang berkelanjutan di Kota Tongyeong dapat menjadi model alternatif untuk penguatan pendidikan karakter dan lingkungan yang ada di Indonesia melalui sistem kebijakan yang berkelanjutan. Kurikulum berbasiskan pada realitas dan kebutuhan peserta didik, serta metode aktif partisipatoris. Komitmen serius pemerintah, masyarakat, dan RCE Tongyeong,membawa paradigma baru dalam pendidikan untuk membuka wawasan bagi peserta didik lebih baik di masyarakat. Penelitian ini menunjukkan bahwa hakikat konsep pendidikan untuk pembangunan yang berkelanjutan sebagai upaya untuk membangun tatanan masyarakat baru yang lebih baik bertujuan untuk keberlangsungan eksistensi kehidupan manusia di bumi hari ini dan masa depan dan isu-isu tentang pendidikan untuk pembangunan yang berkelanjutan masih kuat menekankan pada isu-isu lingkungan, khususnya pendidikan lingkungan di sekolah-sekolah.

\section{DAFTAR PUSTAKA}

\section{Buku dan Dokumen}

Booklet RCE Tongyeong, 2007

Chamberlain, Leo M dan Kindred, Leslie W, 1966, The Teacher and School Organization, Prentice-Hall, New Jersey.

Declaration Bonn, 2009, www.esd-world-conference-2009.org.

Elias, Derek, Nakayama, Shuichi and Hargreaves,Lucy (ed.), 2005, A Situational Analysis of Education for Sustainable Development in the Asia-Pacific Region, Revised Edition, Working paper report: 
Asia Pacific Regional Strategy for Education for Sustainable Development, second edition UNESCO Asia Pacific Regional Bureau for Education, Bangkok.

Ginkel, van Hans, 2006, "Mobilizing for sustainable development", in International Conference Globalization and Education for Sustainable Development Sustaining the Future, (editor:Laura Wong), UNESCO, Paris, hal. 20-27.

2012, "World 5.0: Globalization and Our Future, Geo-political and Socio-Economic Perspectives on the Main Processes Shaping Our Future World", Open Lecturer, The Hague.

Gothenburg (2008).

Mahruf dkk (2011).

Noddings, Nel, 2007, Philosophy of Education, Westview press, Cambridge.

Novak,Joseph D,1977, A Theory of Education. New York: Cornell University.

Ransoo,Kim, 1984,Korean Education: in Research Perspectives, Jong-Gak Publishing, Seoul.

Suhartono, Suparlan, 2009, Filsafat Pendidikan,Ar-Ruzzmedia, Yogyakarta.

UNESCO, 1978, "Intergovernmental Conference on Environmental education, Tblisi 14-26 October 1997", final report, UNESCO, Paris.

2006," Framework for the UNDESD International Implementation Scheme", UNESCO, Paris.

2005, United Nations Decade Education for Sustainable Development (2005-2014): International Implementation Scheme, Division for the Promotion of Quality Education, Paris.

2007, "Highlights on DESD Progress to Date April 2007". Section for DESD Coordination (ED/UNP/DESD) UNESCO, 7 Place de Fontenoy, 75352 Paris 07 SP, France esddecade @unesco.org-- www.unesco.org/education/desd. 


\section{Jurnal}

Ginkel,Hans Van, 2006,Global Efforts on Education for Sustainable Development and UNU Regional Centres of Expertise on EfSD, Workshop on Education for Sustainable Development and the role of RCE Tongyeong,29-30 March 2006, Tongyeong City.

Lee, Sun-Kyung, 2011, The Present Status and Issues of Education for Sustainable Development (ESD) for Mid-term Evaluation of UN Decade of ESD. Tongyeong ESD International Forum. RCE Tongyeong. hal.130-136.

Mahruf.M. C, Shohel, and Howes, Andrew J, 2011, Models of Education for Sustainable Development and Nonformal Primary Education in Bangladesh. Journal of Education for Sustainable Development, Mar 3 2011, pp.129-139.downloaded from http:// jsd. sagepub.com at Gyeongsang National University April 23, 2012.

Rio Declaration on Environment and Development, Downloaded on 24 April 2012 03: 45 http://www.unep.org/Documents.Multi lingual/Default.asp?documentid=78\&articleid=1163.

\section{Artikel}

Kompas, 4 Desember 2013, Konferensi Perubahan Iklim 2013, Komitmen Masih Setengah Hati, hal.14. 4 November 2013, Soal Iklim, Peran Perguruan Tinggi Belum Optimal, hal.12.

Kompas, 7 Januari 2014, hal.14.

Kedaulatan Rakyat, Cuaca Ekstrem di AS, Suhu Minus 34 Derajat, 11 Desember 2013 hal. 11. 2013, Tajuk Rencana,Krisis Ekologi Tetap Menghantui, 9 November 2013, hal.14.

\section{Internet}

The Declaration of Thessaloniki, UNESCO-EPD-97/Conf.401/CLD2,12 December1997,http://www.unesco.org/new/en/education/t hemes/leading-the-international-agenda/education-for- 
sustainable-development/sustainable-development/, diakses 20 februari 2012 jam 6:28.

Http://www.unesco.org/new/en/education/themes/leading-theinternational-agenda/education-for-sustainabledevelopment/three-terms-one-goal/, diakses 18 November 2013 10:54.

Http://english.moe.go.kr/enMain.do diakses 15 November 2013 19:00 Http://www2.leuphana.de/vcse/uploads/media/Declarations_on_hig her_education_and_sustainable_development.pdf, akses 18 November 201315:35. 